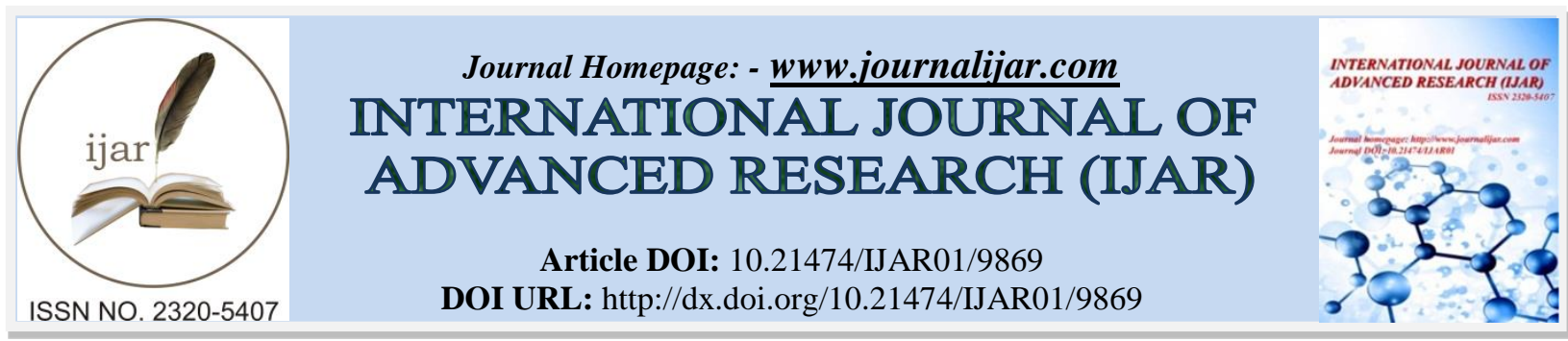

RESEARCH ARTICLE

\title{
AWARENESS OF BIOMEDICAL WASTE (BMW) MANAGEMENT AMONG DENTAL AND MEDICAL STUDENTS.
}

\author{
Mohammad Abdulkhaliq Al-Sayyali ${ }^{1}$, Roshan Noor Mohamed ${ }^{2}$, Sakeenabi Basha ${ }^{3}$, Yousef Al Thomali ${ }^{3}$, \\ Ammar Saleh Al-Shamrani ${ }^{4}$ and Mohammed Khalil Fahmi ${ }^{5}$. \\ 1. Dental Graduate Doctor, Faculty of Dentistry, Taif University, KSA. \\ 2. Assistant Professors, Preventive Dental Sciences Department, Faculty of Dentistry, Taif University, KSA. \\ 3. Head of Preventive Dental Sciences Department, Faculty of Dentistry, Taif University, KSA. \\ 4. Dean, Faculty of Dentisty, Taif University, KSA. \\ 5. Head of Restorative Dental Sciences Department, Faculty of Dentistry, Taif University, KSA
}

\section{Manuscript Info}

Manuscript History

Received: 08 August 2019

Final Accepted: 10 September 2019

Published: October 2019

Key words:-

Biomedical waste, Hospital waste, Hospital hazard, Biomedical hazard.

\section{Abstract}

Background: Hazardous biomedical waste management should be addressed adequately and appropriately to prevent any harmful effects on the people providing health care services or to the patients receiving treatment.

Material and Methods: The study was a cross-sectional questionnairebased survey. The target population was the dental and medical students of Taif University. 145 students agreed to participate in the study voluntarily which included 69 dental and 76 medical students. Chi-square test was performed and the level of significance was set at $p$ $<0.05$.

Results: Around 77 percent of total participants agree that improper waste management will cause various health hazards. 69 percent of dental and 54 percent of medical students were aware that their hospital produces biomedical waste. Regarding the practice of disposing of used disposable plastic items, 11.6 percent of dental and 7 percent of medical students responded correctly. The participants responding falsely were 57 percent and 31.57 percent for dental and medical students respectively $(\mathrm{p}=0.03$ ). The color of the bag used to dispose of an extracted tooth was corrected responded by 7.24 percent of dental and 11.84 percent of medical students $(p=0.06)$.

Conclusion: The study showed average students' awareness and knowledge about BMW management and disposal. The university should activate education programs, courses and workshops to increase awareness among students.

Copy Right, IJAR, 2019,. All rights reserved.

\section{Introduction:-}

In health care sector a huge amount of biomedical waste (BMW) is produced in the process of diagnosis and treatment which may be hazardous to all those who come in contact with this waste (Shalini S, 2010). Hazardous waste management is a concern to the entire health care establishments, which should be addressed adequately and appropriately to prevent any harmful effects on the people providing health care services or to the patients receiving treatment or to the environment at large. 
The biomedical waste management and handling rules have been notified in by respective medical health councils of each country governing the health care sector according to the guidelines of the World Health Organization (WHO) (Rushbrook, Philip, WHO, 1999) (Al-Zahrani MA, et al., 1998). The rule makes it mandatory for the healthcare establishments to segregate, disinfect and dispose of their waste in an eco-friendly manner. An important pre-requisite and key to a successful waste management program is segregation which is the separation of different types of waste as per treatment and disposal option. Segregation and collection of various categories of waste should be done at the source, in separate containers so that each category is treated suitably to render it harmless. For waste management to be effective, the waste should be managed at every step, from acquisition to disposal (Sood AG, Sood A, 2011).

The Biomedical waste management and its practice should be stressed among students pursuing healthcare training. With this background, the present study was conducted to assess the awareness of biomedical waste management among dental and medical students through a pretested questionnaire.

\section{Materials and methods:-}

The study was a cross-sectional questionnaire-based survey. The target population was the dental and medical students of Taif University. The present study was approved by the Institutional Review Board, Faculty of Dentistry, Taif University.

A prefabricated validity tested questionnaire was administered to the target population. The questionnaire was divided into two parts. The first part consisted of eight questions on awareness of biomedical waste management. The second part contained 5 questions on biomedical waste management practices. All questions in the questionnaire were close-ended. The items in the questionnaire are summarized in Table 1.

All the students attending the clinics were invited to participate in the study. Subsequently, 145 students agreed to participate in the study voluntarily which included 69 dental and 76 medical students.

All returned questionnaires were coded and analyzed. Results were expressed as a number and percentage of respondents for each question and were analyzed using the SPSS Version 17 software. Chi-square test, Kruskal Wallis -ANOVA followed by Man Whitney U test was performed for statistical analysis with a level of significance set at $p<0.05$.

\section{Results:-}

The results of agree response from the study participants regarding the awareness of BMW management is summarized in table-2. Around 77 percent of total participants agree that improper waste management will cause various health hazards (Table-2). This result was not statistically significant when compared between dental and medical students $(\mathrm{p}=0.13)$. Among the total sample size, 57 percent of participants agree that BMW management is a team effort. When compared between responses of dental and medical students, 68 percent and 36 percent agree for the same respectively $(\mathrm{p}=0.04)$ (Table 3$)$.

Seventy percent of study participants (69 percent dental and 54 percent medical students) were aware that their hospital produces biomedical waste. There was agreement among dental and medical students regarding the need for regular educational programs on BMW management with 76 percent and 61 percent of dental and medical students agreeing respectively $(\mathrm{p}=0.11)$ (Table 3$)$.

The comparison of BMW management awareness between dental and medical students is summarized in Table 3. Table 4 shows the comparison of various responses to BMW management practices among dental and medical students. 69.56 percent of dental and 67 percent of medical students responded correctly to having different colored bags to dispose of different types of wastes $(\mathrm{p}=0.06)$. Regarding the practice of disposing of used disposable plastic items, 11.6 percent of dental and 7 percent of medical students responded correctly. The participants responding falsely was 57 percent and 31.57 percent for dental and medical students respectively ( $\mathrm{p}=0.03)$ (Table 4). The color of the bag used to dispose of an extracted tooth was corrected responded by 7.24 percent of dental and 11.84 percent of medical students $(\mathrm{p}=0.06)$.

The comparison of correct responses with combined other responses by dental and medical students is summarized in Table 5. There is a statistically significant difference between correct response and combined other responses for 
all the questions regarding BMW management practices $(\mathrm{p}<0.05)$ (Table 5) between dental and medical students. The combined other response were of higher percentage compared to the correct response for all the questions regarding BMW management practices except for the question related to having color bags for a different type of waste (Table 5).

\section{Discussion:-}

It is documented by earlier researchers that $75-90 \%$ of generated BMW is a non-risk waste, where the remaining 10-25\% considered hazardous and may cause serious injuries and infectious diseases (Rushbrook, Philip, WHO, 1999) (Al-Zahrani MA, et al., 1998). Both dental and medical students are exposed to either infectious or noninfectious waste which can lead to the spread of infection or result in serious injuries such as toxicity, genotoxicity, carcinogenic effect, burns, and corrosions (Sood AG, Sood A, 2011).

In Saudi Arabia, the amount of healthcare risk waste generated by health establishments has increased several folds with an increase in health care service providers and facilities (Mohammed A. Al-Zahrani et al., 2000). Although, there is an increased global awareness among health professionals about the hazards and also appropriate management techniques, the level of awareness in Saudi Arabian student's perusing health care studies either medical or dental is found to be not extensively studied and reported.

The present study was conducted on a predesigned and pretested questionnaire and cross-sectional the study design was followed. The similar study design has been followed by several past researchers to measure the awareness and practices of BMW management (Mohammed A. Al-Zahrani et al., 2000; Narang RS et al., 2012; Ranjan R et al., 2016). In the present study, 77 percent of total participants responded that improper waste management can cause serious health hazards. This finding is slightly higher compared to similar past research conducted by Rajeev Ranjan et al., 2016 , who reported 61 percent agreement in their study. 68 percent of dental students and 47 percent of medical students (Total 57\% of total participants) agreed that BMW management is the responsibility of teamwork, whereas in the study conducted by Alok Sharma et al., 2013 reported a 65 percent agreement to a similar query.

It was noted by the results of the present study 70.34 percentage of the total participant (69.56 percent of dental and 71.05 percent of medical students) agree that their hospital/clinic generate biomedical waste, whereas some of the previous researchers have reported as much as 100 percent agree to this question in their study (Narang RS et al., 2012). The definitive reason for this variation in response cannot be explained, however, lack of knowledge regarding the classification of biomedical waste among students newly entering clinics may be effecting this response.

In the present study, 63 percent and 60 percent of dental and medical students respectively agreed that there is a policy in their faculty for management of BMW. This response shows a lot of variations among some of the past studies (Kishore J et al., 2000; Centers for Disease Control and Prevention, 2001). It also highlights the fact that the students are not well oriented towards the BMW management policy document followed by the faculty. The higher response rate in some of the previous research can be because they considered the response from the dentists and dental hygienists/nurse (Narang RS et al., 2012) who have much better knowledge in contrast to the student population which is included in the present study.

Regarding the importance of maintaining BMW records, 54.48 percent of total participants respond that it is mandatory for keeping BMW records. Although the agree the response rate for this query was higher in the present study compared to some of the past research (Narang RS et al., 2012) it still cannot be considered adequate. The recording of BMW generated is primarily performed by the auxiliary personal wherein dental or medical students may not be directly involved in this documentation. 47.5 percent of participants in the present study respond that their knowledge about BMW management is through academic training and regarding the importance of regular educational programs on BMW management, 78.6 percent of the total participants agree that it is essential.

The segregation of different type of Biomedical Waste and its disposal according to the accepted universal guidelines involve deferent color-coded bags (Mohammed A. Al-Zahrani et al., 2000; Centers for Disease Control and Prevention, 2001; Pruss, A et al., 1999). The dental and medical students are expected to be aware of the color coding for managing biomedical waste generated during their health care practice. In the present study, 68 percent of the total participants were aware of color coding for BMW management. The percentage of awareness was higher in the present study when compared to some of the past studies (Punchanuwat K et al., 1998). The reason for this may be the higher emphasis on BMW management in the faculty during clinical and academic training of the students. 
Alarming observations recorded by both dental and medical students regarding the disposal of each type of waste in different color-coded bags in the present study. Only 10.3 percent of total participants responded correctly to color bags used for disposal of the used disposable plastic item. The correct response for color bags used for disposal of soiled dressings and impression materials was only 11.7 percent and for disposal of the extracted tooth, it was 9.6 percent. These findings from the present study highlight the fact that the students perusing health care training are not adequately aware of BMW management practices. Understanding different types of BMW and selecting appropriate color-coded bags for their disposal is the area of lacking among students in the present study. Although, varying levels of awareness have been reported by several other researchers for BMW disposal practices in different parts of the world (Narang RS et al., 2012; Rajeev Ranjan et al., 2016; Kundapur R et al., 2014; Sanjeev R et al., 2014; Reddy LK, Al Shammari F 2017; Almuneef, M, Memish, Z 2003). The finding of the present study cannot be directly compared to past research since most of the past studies were conducted on health care workers mainly doctors, dentists, and nurses, whereas the present study involves students perusing health studies.

To conclude, within the limitations of the present study, it is clear that the awareness and practices of BMW management among the dental and medical students of Taif University is not adequate. Therefore, it is recommended that more educational programs, courses, and workshops should be conducted for the effective orientation of the students regarding BMW management for the safety of future health professionals and the environment as a whole.

Table 1:-Questionnaire for awareness and practices of BMW Management

\begin{tabular}{|c|c|c|c|c|c|}
\hline Slno & Questions & \multirow{2}{*}{\multicolumn{4}{|c|}{ Responses }} \\
\hline \multicolumn{2}{|c|}{ A. Awareness of BMW Management: } & & & & \\
\hline 1. & $\begin{array}{l}\text { Can improper waste management cause } \\
\text { various health hazards? }\end{array}$ & Yes & \multicolumn{2}{|l|}{ No } & Don't Know \\
\hline 2. & $\begin{array}{l}\text { Safe management of biomedical waste is } \\
\text { the team work of dental/medical students, } \\
\text { faculty \& auxiliaries. }\end{array}$ & Yes & \multicolumn{2}{|l|}{ No } & Don’t Know \\
\hline 3. & $\begin{array}{l}\text { Does your hospital/clinic generate } \\
\text { biomedical waste? }\end{array}$ & Yes & \multicolumn{2}{|l|}{ No } & Don’t Know \\
\hline 4. & $\begin{array}{l}\text { Are there any policies laid down by Saudi } \\
\text { Administration for BMW management? }\end{array}$ & Yes & \multicolumn{2}{|l|}{ No } & Don't Know \\
\hline 5. & $\begin{array}{l}\text { Is there any biomedical waste disposal } \\
\text { policy in your hospital/faculty? }\end{array}$ & Yes & \multicolumn{2}{|l|}{ No } & Don't Know \\
\hline 6. & $\begin{array}{l}\text { Is maintaining BMW records mandatory } \\
\text { in hospital/clinic? }\end{array}$ & Yes & \multicolumn{2}{|l|}{ No } & Don't Know \\
\hline 7. & $\begin{array}{l}\text { Your Knowledge about BMW } \\
\text { management is from Academic teaching. }\end{array}$ & Yes & \multicolumn{2}{|l|}{ No } & Don’t Know \\
\hline 8. & $\begin{array}{l}\text { Should there be regular educational } \\
\text { programs on biomedical waste } \\
\text { management? }\end{array}$ & Yes & \multicolumn{2}{|l|}{ No } & Don’t Know \\
\hline \multicolumn{6}{|c|}{ B. BMW Management Practices; } \\
\hline 1. & $\begin{array}{l}\text { Are different colored bags used to dispose } \\
\text { different types of waste? }\end{array}$ & Yes & \multirow[b]{2}{*}{$\begin{array}{l}\text { Red } \\
\text { bag }\end{array}$} & & Don't Know \\
\hline 2. & $\begin{array}{l}\text { Used disposable plastic items (e.g., } \\
\text { catheter) are disposed of in: }\end{array}$ & $\begin{array}{l}\text { Yellow } \\
\text { bag }\end{array}$ & & Black Bag & $\begin{array}{l}\text { Don’t } \\
\text { Know }\end{array}$ \\
\hline 3. & $\begin{array}{l}\text { Soiled dressings and used impression } \\
\text { materials are disposed of in: }\end{array}$ & $\begin{array}{l}\text { Blue/ } \\
\text { white bags }\end{array}$ & $\begin{array}{l}\text { Red } \\
\text { bag }\end{array}$ & Black Bag & $\begin{array}{l}\text { Don't } \\
\text { Know }\end{array}$ \\
\hline 4. & $\begin{array}{l}\text { Used sharps and needles are disposed of } \\
\text { in: }\end{array}$ & $\begin{array}{l}\text { Yellow } \\
\text { bags }\end{array}$ & $\begin{array}{l}\text { Rigid/puncture- } \\
\text { proof container }\end{array}$ & $\begin{array}{l}\text { Red } \\
\text { bag }\end{array}$ & $\begin{array}{l}\text { Don't } \\
\text { Know }\end{array}$ \\
\hline 5. & $\begin{array}{l}\text { Extracted teeth and human tissue are } \\
\text { disposed of in: }\end{array}$ & $\begin{array}{l}\text { Yellow } \\
\text { bag }\end{array}$ & $\begin{array}{l}\text { Red } \\
\text { bag }\end{array}$ & Black Bag & $\begin{array}{l}\text { Don't } \\
\text { Know }\end{array}$ \\
\hline
\end{tabular}


Table 2:-BMW Management awareness comparison of agree response and a combined other responses.

\begin{tabular}{|c|c|c|c|}
\hline \multirow[t]{2}{*}{ Questions } & \multicolumn{2}{|c|}{$\begin{array}{l}\text { Agree response by the Study participants } \\
(\mathrm{n}=145)\end{array}$} & \multirow[t]{2}{*}{$\begin{array}{l}\text { Chi-square test, } \\
\text { p value }\end{array}$} \\
\hline & $\begin{array}{l}\text { Agree } \\
\text { Response }\end{array}$ & $\begin{array}{l}\text { A combined other } \\
\text { response }\end{array}$ & \\
\hline $\begin{array}{l}\text { Can improper waste management cause various health } \\
\text { hazards? }\end{array}$ & $\begin{array}{l}112 \\
(77.24 \%)\end{array}$ & $\begin{array}{l}33 \\
(22.75 \%)\end{array}$ & 0.01 \\
\hline $\begin{array}{l}\text { Safe management of biomedical waste is the team } \\
\text { work of dental/medical students, faculty } \& \text { auxiliaries }\end{array}$ & $\begin{array}{l}83 \\
(57.24 \%)\end{array}$ & $\begin{array}{l}62 \\
(42.75 \%)\end{array}$ & 0.06 \\
\hline Does your hospital/clinic generate biomedical waste? & $\begin{array}{l}102 \\
(70.34 \%) \\
\end{array}$ & $\begin{array}{l}43 \\
(29.66 \%) \\
\end{array}$ & 0.01 \\
\hline $\begin{array}{l}\text { Are there any policies laid down by Saudi } \\
\text { Administration for BMW management? }\end{array}$ & $\begin{array}{l}93 \\
(64.14 \%)\end{array}$ & $\begin{array}{l}52 \\
(35.86 \%)\end{array}$ & 0.02 \\
\hline $\begin{array}{l}\text { Is there any biomedical waste disposal policy in your } \\
\text { hospital/faculty? }\end{array}$ & $\begin{array}{l}90 \\
(62.07 \%)\end{array}$ & $\begin{array}{l}55 \\
(37.93 \%)\end{array}$ & 0.03 \\
\hline $\begin{array}{l}\text { Is maintaining } \text { BMW records mandatory in } \\
\text { hospital/clinic? }\end{array}$ & $\begin{array}{l}79 \\
(54.48 \%)\end{array}$ & $\begin{array}{l}66 \\
(45.52 \%)\end{array}$ & 0.08 \\
\hline $\begin{array}{l}\text { Your Knowledge about BMW management is from } \\
\text { Academic teaching }\end{array}$ & $\begin{array}{l}69 \\
(47.59 \%)\end{array}$ & $\begin{array}{l}76 \\
(52.41 \%)\end{array}$ & 0.10 \\
\hline $\begin{array}{l}\text { Should there be regular educational programs on } \\
\text { biomedical waste management? }\end{array}$ & $\begin{array}{l}114 \\
(78.62 \%)\end{array}$ & $\begin{array}{l}31 \\
(21.38 \%)\end{array}$ & 0.01 \\
\hline \multicolumn{4}{|c|}{$\begin{array}{l}\text { Foot note: } \mathrm{p}<0.05=\text { Significant } \\
\text { Agree response- include "Yes" response, Combined other response include "No" "Don’t know" and "No response" }\end{array}$} \\
\hline
\end{tabular}

Table 3:-Awareness of Biomedical Waste (BMW) Management among Dental and Medical students.

\begin{tabular}{|l|l|l|l|}
\hline Questions & Agree response by the students & $\begin{array}{l}\text { Chi-square test, } \\
\mathrm{p} \text { value }\end{array}$ \\
\cline { 2 - 4 } & Dental $(\mathrm{n}=69)$ & Medical $(\mathrm{n}=76)$ & 0.13 \\
\hline $\begin{array}{l}\text { Can improper waste management cause various health } \\
\text { hazards? }\end{array}$ & $51(73.91 \%)$ & $61(80.26 \%)$ & 0.04 \\
\hline $\begin{array}{l}\text { Safe management of biomedical waste is the team work } \\
\text { of dental/medical students, faculty \& auxiliaries }\end{array}$ & $47(68.11 \%)$ & $36(47.36 \%)$ & 0.12 \\
\hline Does your hospital/clinic generate biomedical waste? & $48(69.56 \%)$ & $54(71.05 \%)$ & 0.11 \\
\hline $\begin{array}{l}\text { Are there any policies laid down by Saudi Administration } \\
\text { for BMW management? }\end{array}$ & $43(62.13 \%)$ & $50(65.78 \%)$ & 0.13 \\
\hline $\begin{array}{l}\text { Is there any biomedical waste disposal policy in your } \\
\text { hospital/faculty? }\end{array}$ & $44(63.76 \%)$ & $46(60.72 \%)$ & 0.09 \\
\hline $\begin{array}{l}\text { Is maintaining BMW records mandatory in } \\
\text { hospital/clinic? }\end{array}$ & $38(55.07 \%)$ & $41(53.94 \%)$ & 0.10 \\
\hline $\begin{array}{l}\text { Your Knowledge about BMW management is from } \\
\text { Academic teaching }\end{array}$ & $29(42.02 \%)$ & $40(52.63 \%)$ & \\
\hline $\begin{array}{l}\text { Should there be regular educational programs on } \\
\text { biomedical waste management? }\end{array}$ & $53(76.81 \%)$ & $61(80.26 \%)$ & 0.11 \\
\hline Foot note: p<0.05=Significant & & \\
\hline
\end{tabular}

Table 4:-Biomedical Waste (BMW) Management practices among dental and medical students.

\begin{tabular}{|c|c|c|c|c|}
\hline \multirow[t]{2}{*}{ Questions } & \multirow[t]{2}{*}{ Responses } & \multicolumn{2}{|c|}{ Type of students } & \multirow{2}{*}{$\begin{array}{l}\text { Chi-square } \\
\text { test, } \\
\text { p value }\end{array}$} \\
\hline & & $\begin{array}{l}\text { Dental } \\
(n=69)\end{array}$ & $\begin{array}{l}\text { Medical } \\
(\mathrm{n}=76)\end{array}$ & \\
\hline Are & Correct & $48(69.56 \%)$ & $51(67.1 \%)$ & 0.06 \\
\hline
\end{tabular}




\begin{tabular}{|c|c|c|c|c|}
\hline \multirow{5}{*}{$\begin{array}{l}\text { colored bags used } \\
\text { to dispose different } \\
\text { types of waste? }\end{array}$} & False & $4(5.79 \%)$ & $6(7.89 \%)$ & 0.08 \\
\hline & No response & $3(4.34 \%)$ & $4(5.26 \%)$ & 0.11 \\
\hline & Don't know & $14(20.28 \%)$ & $15(19.73 \%)$ & 0.09 \\
\hline & Kruskal Wallis -ANOVA & 0.03 & 0.03 & \\
\hline & Man Whitney U test & $C>O R$ & $C>O R$ & \\
\hline \multirow{6}{*}{$\begin{array}{l}\text { Used disposable } \\
\text { plastic items (e.g., } \\
\text { catheter) are } \\
\text { disposed of in } \\
\text { which bags? }\end{array}$} & Correct & $8(11.6 \%)$ & $7(9.21 \%)$ & 0.08 \\
\hline & False & $40(57.97 \%)$ & $24(31.57 \%)$ & 0.03 \\
\hline & No response & $4(5.79 \%)$ & $4(5.26 \%)$ & 0.11 \\
\hline & Don't know & $17(24.63 \%)$ & $41(53.94 \%)$ & 0.01 \\
\hline & Kruskal Wallis -ANOVA & 0.01 & 0.01 & \\
\hline & Man Whitney U test & $\mathrm{F}>\mathrm{OR}$ & $\mathrm{DN}>\mathrm{OR}$ & \\
\hline \multirow{6}{*}{$\begin{array}{l}\text { Soiled dressings } \\
\text { and } \\
\text { impression } \\
\text { materials are } \\
\text { disposed of in } \\
\text { which bags? }\end{array}$} & Correct & $11(15.94 \%)$ & $6(7.89 \%)$ & 0.05 \\
\hline & False & $25(36.23 \%)$ & $18(23.68 \%)$ & 0.06 \\
\hline & No response & $3(4.34 \%)$ & $4(5.26 \%)$ & 0.12 \\
\hline & Don't know & $30(43.47 \%)$ & $48(63.15 \%)$ & 0.04 \\
\hline & Kruskal Wallis -ANOVA & 0.04 & 0.03 & \\
\hline & Man Whitney U test & $\begin{array}{l}\mathrm{DN}>\mathrm{C} \& \mathrm{NR} \\
\mathrm{F}>\mathrm{C} \& \mathrm{NR}\end{array}$ & $\mathrm{DN}>\mathrm{OR}$ & \\
\hline \multirow{6}{*}{$\begin{array}{lr}\text { Used sharps } & \text { and } \\
\text { needles } & \text { are } \\
\text { disposed of in } & \end{array}$} & Correct & $30(43.47 \%)$ & $24(31.57 \%)$ & 0.04 \\
\hline & False & $15(21.73 \%)$ & $24(31.57 \%)$ & 0.06 \\
\hline & No response & $3(4.34 \%)$ & $4(5.26 \%)$ & 0.13 \\
\hline & Don't know & $21(30.43 \%)$ & $24(31.57 \%)$ & 0.09 \\
\hline & Kruskal Wallis -ANOVA & 0.06 & 0.07 & \\
\hline & Man Whitney U test & NA & NA & \\
\hline \multirow{6}{*}{$\begin{array}{l}\text { Extracted teeth and } \\
\text { human tissue are } \\
\text { disposed of in } \\
\text { which bags? }\end{array}$} & Correct & $5(7.24 \%)$ & $9(11.84 \%)$ & 0.06 \\
\hline & False & $38(55.07 \%)$ & $21(27.63 \%)$ & 0.03 \\
\hline & No response & $3(4.34 \%)$ & $4(5.26 \%)$ & 0.12 \\
\hline & Don't know & $23(33.33 \%)$ & $42(55.26 \%)$ & 0.03 \\
\hline & Kruskal Wallis -ANOVA & 0.04 & 0.04 & \\
\hline & Man Whitney U test & $\mathrm{F}>\mathrm{OR}$ & $\mathrm{DN}>\mathrm{OR}$ & \\
\hline
\end{tabular}

Table 5:-BMW Management practices comparison of correct response and a combined other responses.

\begin{tabular}{|c|c|c|c|c|}
\hline \multirow[t]{2}{*}{ Questions } & \multirow{2}{*}{$\begin{array}{l}\text { Study } \\
\text { Participants }\end{array}$} & \multicolumn{2}{|c|}{ Response from students } & \multirow{2}{*}{$\begin{array}{l}\text { Chi- } \\
\text { square } \\
\text { test, p } \\
\text { value }\end{array}$} \\
\hline & & $\begin{array}{l}\text { Correct } \\
\text { response } \\
\mathrm{n}(\%)\end{array}$ & $\begin{array}{l}\text { Combined } \\
\text { other } \\
\text { response } \\
\mathrm{n}(\%)\end{array}$ & \\
\hline \multirow[t]{2}{*}{$\begin{array}{l}\text { Are different colored bags used to dispose different } \\
\text { types of waste? }\end{array}$} & $\begin{array}{l}\text { Dental } \\
(\mathrm{n}=69)\end{array}$ & $\begin{array}{l}48 \\
(69.56 \%)\end{array}$ & $\begin{array}{l}21 \\
(30.01 \%)\end{array}$ & 0.04 \\
\hline & $\begin{array}{l}\text { Medical } \\
(\mathrm{n}=76)\end{array}$ & $\begin{array}{l}51 \\
(67.01 \%)\end{array}$ & $\begin{array}{l}25 \\
(32.89 \%)\end{array}$ & 0.04 \\
\hline \multirow[t]{2}{*}{$\begin{array}{l}\text { Used disposable plastic items (e.g., catheter) are } \\
\text { disposed of in which bags? }\end{array}$} & $\begin{array}{l}\text { Dental } \\
(\mathrm{n}=69)\end{array}$ & $\begin{array}{l}8 \\
(11.59)\end{array}$ & $\begin{array}{l}61 \\
(88.40 \%)\end{array}$ & $<0.01$ \\
\hline & $\begin{array}{l}\text { Medical } \\
(\mathrm{n}=76)\end{array}$ & $\begin{array}{l}7 \\
(9.21 \%)\end{array}$ & $\begin{array}{l}69 \\
(90.78)\end{array}$ & $<0.01$ \\
\hline \multirow[t]{2}{*}{$\begin{array}{l}\text { Soiled dressings and used impression materials are } \\
\text { disposed of in which bags? }\end{array}$} & $\begin{array}{l}\text { Dental } \\
(\mathrm{n}=69)\end{array}$ & $\begin{array}{l}11 \\
(15.94 \%)\end{array}$ & $\begin{array}{l}58 \\
(84.05 \%)\end{array}$ & $<0.01$ \\
\hline & $\begin{array}{l}\text { Medical } \\
(\mathrm{n}=76)\end{array}$ & $\begin{array}{l}6 \\
(7.89 \%)\end{array}$ & $\begin{array}{l}70 \\
(92.10 \%)\end{array}$ & $<0.01$ \\
\hline \multirow[t]{2}{*}{ Used sharps and needles are disposed of in } & $\begin{array}{l}\text { Dental } \\
(\mathrm{n}=69)\end{array}$ & $\begin{array}{l}30 \\
(43.47 \%)\end{array}$ & $\begin{array}{l}39 \\
(56.52 \%)\end{array}$ & 0.13 \\
\hline & Medical & 24 & 52 & 0.03 \\
\hline
\end{tabular}




\begin{tabular}{|c|c|c|c|c|}
\hline & $(n=76)$ & $(31.57 \%)$ & $(68.42 \%)$ & \\
\hline \multirow[t]{2}{*}{$\begin{array}{l}\text { Extracted teeth and human tissue are disposed of in } \\
\text { which bags? }\end{array}$} & $\begin{array}{l}\text { Dental } \\
(n=69)\end{array}$ & $\begin{array}{l}5 \\
(7.24 \%)\end{array}$ & $\begin{array}{l}64 \\
(92.75 \%)\end{array}$ & $<0.01$ \\
\hline & $\begin{array}{l}\text { Medical } \\
(\mathrm{n}=76)\end{array}$ & $\begin{array}{l}9 \\
(11.84 \%)\end{array}$ & $\begin{array}{l}67 \\
(88.15)\end{array}$ & $<0.01$ \\
\hline
\end{tabular}

\section{References:-}

1. Almuneef, M. and Memish, Z. "Effective medical waste management: it can be done", American Journal of Infection Control. 2003; 31(3): 188-92.

2. Al-Zahrani MA, Al-Shanshouri MA, Fakhri ZI. Guide of Healthcare Waste Management. Ministry of Health, Saudi Arabia, 1998.

3. Centers for Disease Control and Prevention (2001), Healthcare Infection Control Practices Advisory Committee (HICPAC), Draft Guideline for Environmental Infection Control in Healthcare Facilities, Altlanta, GA, pp. 96101.

4. Kishore J, Goel P, Sagar B, Joshi TK. Awareness about biomedical waste management and infection control among dentists of a teaching hospital in New Delhi, India. Indian journal of dental research: official publication of Indian Society for Dental Research. 2000; 11(4):157-61.

5. Kundapur R, Bhat T, Badiger S, Ballal R. The awareness in biomedical waste management of nursing staff at a tertiary care hospital of Mangalore, South India. Nitte University Journal of Health Science. 2014; 4(4):73.

6. Mohammed A. Al-Zahrani, Zuheir I. Fakhri, Mohammed A. Al-Shanshouri,

7. Mohammed H. Al-Ayed. Healthcare risk waste in Saudi Arabia- Rate of generation. Saudi Medical Journal 2000; Vol. 21 (3):245-250.

8. Narang RS, Manchanda A, Singh S, Verma N, Padda S. Awareness of biomedical waste management among dental professionals and auxiliary staff in Amritsar, India. Oral Health Dent Manag. 2012;11(4):162-8.

9. Pruss, A., Giroult, E. and Rushbrook, D. (1999), Safe Management of Wastes from Health-care Activities, World Health Organization, Geneva.

10. Punchanuwat K, Drummond BK, Treasure ET. An investigation of the disposal of dental clinical waste in Bangkok. International dental journal. 1998; 48(4):369-73.

11. Ranjan R, Pathak R, Singh DK, Jalaluddin M, Kore SA, Kore AR. Awareness about biomedical waste management and knowledge of effective recycling of dental materials among dental students. J Int Soc Prevent Communit Dent 2016;6:474-9.

12. Reddy LK, Al Shammari F. Evaluation of biomedical waste management in primary health care centres in Saudi Arabia: a knowledge, attitudes and practices study. Eastern Mediterranean Health Journal 2017; 23(9):637-641.

13. Rushbrook, Philip. \& Pruss, A. \& Giroult, E. \& World Health Organization. (1999). Safe management of wastes from health-care activities. Geneva : World Health Organization.

14. Sanjeev R, Kuruvilla S, Subramaniam R, Prashant PS, Gopalakrishnan M. Knowledge, attitude, and practices about biomedical waste management among dental healthcare personnel in dental colleges in Kothamangalam: A cross-sectional study. Health Sci. 2014; 1(3):1-2.

15. Shalini S. Awareness about Bio-Medical Waste Management among Health Care Personnel of some Important Medical Centers in Agra. International Journal of Environment Science and Development 2010;1:251-5.

16. Sharma A, Sharma V, Sharma S, Singh P. Awareness of biomedical waste management among health care personnel in Jaipur, India. Oral Health Dent Manag. 2013; 12 (1):32-40.

17. Sood AG, Sood A. Dental perspective on biomedical waste and mercury management: A knowledge, attitude and practice survey. Ind J Dent Res 2011; 22: 371-5. 